4. The peaks of fluorescence spectra of urinary estrone, estriol and estradiol have been observed at $485 \mathrm{~m} \mu$ and $490 \mathrm{~m} \mu$.

5. It was found that Vitamin $\mathbf{B}_{1}, \mathbf{B}_{2}, \mathbf{B}_{6}$, Folic acid and their intermediates which excreted in the urine after administration of Pan-vitamin did not effect to fluorescence spetrum.

6. From above results, narrow band filter at peak of spectrum is most suitable for detection of estrogen fluorescence. We have used $\mathrm{V}_{2}$ as the primary filter and one consisted of combination of narrow band filter (at $485 \mathrm{~m} \mu$ and $490 \mathrm{~m} \mu$ for estrone, estriol and estradiol) and $\mathrm{O}_{2}$ (transmission maximum over $450 \mathrm{~m} \mu)$ as the secondary filters.

\title{
Study on the Corticoid-Like Action of Glycyrrhizin
}

\author{
By \\ Saburo YANO \\ Department of Internal Medicine, Osaka Univ. (Director : Prof. Dr. I. Donomae)
}

A study is made of effects of glycyrrhizin on the metabolism of hydrocortisone using rat liver homogenate or its supernatant.

The result obtained are as follows :

1. Glycyrrhizin inhibited the degradation of sidechain as well as the reduction of $4^{4-3}$ ketone.

2. Glycyrrhezinic acid was found to be the very agent to inhibit the metabolism of hydrocortisone.

3. Glycyrrhizin had no effect upon the degradation of sidechain of tetrahydrohydrocortisone. It is assumed that glycyrrhizin specifically inhibited the reduction of $4^{4-3}$ ketone and acted indirectly upon the degradation of sidechain.

4. Glycyrrhizin also inhibited the reduction of $\mathbf{4}^{4}-3$ ketone of DOC and progesterone.

5. It is suggested that glycyrrhizin inhibit competitively the metabolism of corticoid and manifest a corticoid-like action.

\section{Phasecontrastmicroscopical and histochemical analysis of cultivated pancreas-tisses of chickembryo, with special reference to the regeneration of the islet cells}

By

\section{Shin-ichi MATSUYAMA M.D., Gonai IWASA and Tadashi TENDA}

The 1st Department of Internal Medicine, the Kyoto Prefectural Medical College

Phasecontrastmicroscopical and histochemical analysis were performed to the cultivated pancreas-tissues of chickembryos at their various periods of incubation.

Pancreas-tissues of chickembryo, when cultivated in vitro in roller tubes, were hept alive during about 5 days or longer in the adequate fluid medium, and luxarious epitheliar sheeths and mitosis of the epitheliar cells could be obtained frequently. A part of these epitheliar cells, belonged to the primary 
undifferentiated pancreatic cells, and acinar cells, which were differentiated from the former cells, were most constantly found and analized by the Azan reaction and Jacobson's stain. But, the regenerations of pancreatic islet cells were not found so frequently, and when we utilized the pancreas from the chickembryos of 7-9 day's incubation, we could occationally found the primary $\beta$-islet cells, that had gomoriphilic protophasmic granules to the Gomori's G.H.P. stain. The periphery of the outgrowths, in general, were more gomoriphilic than the central portion of the epitheliar sheeths, then, this portion was suggested to be functionally most important in the whole area of the outgrowths.

\section{A Histological Study upon the Mechanism of the Sulfonyl-Urea.} - Chiefly by Ultravioletray Microscope -

\section{Hideo YOSHIDA, Sadayoshi YOKOH, Osamu AOGHI, Michihiko IIZUKA and Michiko KUWATA.}

The ultravioletray microscopic and histological observations upon Langerhans' islet of the rabbits which administrated sulfonyl-urea were performed, and results were as follows:

1) Ultravioletray absorption of the Langerhans' islet ( $2650 \AA$ and $2890 \AA)$ was considerably less compared with acinar cells of the pancreas.

2) Among the normal islet cells, two types of them were able to distinguish. There were, alpha cell which has distinct nucleolus, and nuclei and protoplasma with poor ultravioletray absorption and beta cell which has undistinct nucleolus, and shows strong and diffuse ultravioletray absoption.

3) After oral dose of sulfonyl-urea, once administration and continued administration, ultravioletrary absorption of beta cell's cytoplasma and nuclei were increased and got their maximum after 1 to 1 and a half hours.

4) Degranulatian of beta granules began a quarter hour after sulfonyl-urea administration and got their maximum after 3 hours, and after 6 hours, degranulation was yet remarkably observed through the Gomori's CHP staining.

5) Along these changings, hypertrophy of beta nucleus and $40 \%$ increase of averaged area was observed by karyometry.

6) The changings after sulfonyl-urea administration $0.5 \mathrm{~g}$ for 10 days were much resembled to that of once administration through Gomori's CHP staining.

7) Atrophy of the beta cells and strong glomeration of beta granules faced to the sinusoid of capillary vesells were observed in the rabbits' islets which administrated the drug once or continued.

8) No such remarkable changings were observed in the cases of sulfonyl-urea $0.1 \mathrm{~g} / \mathrm{kg}$ int. v. administration for 1 month as oral dosed group.

9) Through-out these above mentioned data, it was conjectured that sulfonyl-urea has the influences upon beta cell to accelerate its function and secrete its insulin then decreases the blood sugar level. 


\section{培養した鷄胎辂組織の観 察}

特にラ氏島細胞の再生について

京都府立医科大学第一内科学教室（主任 故 舘石 叔教授）

\begin{tabular}{|c|c|}
\hline 松 & 山 \\
\hline 岩 & 佐 \\
\hline 天 & \\
\hline
\end{tabular}

\section{I.はしが}

搭ラ氏島 $\beta$ 紐胞がインシュリンを分泌し，全身の糖代謝調節に枢要な位置を占めるととは今日既に定説と なつており，又 $\alpha$ 細胞も Glucagon を分琅する細胞として，最近諸家の注目を集める処となつた。

著者らは，故舘石教授の下にて，膵ラ氏島細胞の体外培養が，果して可能であるか否かを検せんとし，先 づ幼弱な䳬胎膵組織の培養を全図した。一般に体外培養に於いては，分化した細胞程その游出は困難であり， 膵細胞中発生学的に高度の分化陼梯にあるラ氏島細胞の体外游出を得るためには，成る可く分化程度の低い 時期に之をとらえるてとが一つの解決の鍵であると考えたがらである。

以下にその実験経過の大要を述べる.

\section{II. 材料及び方法}

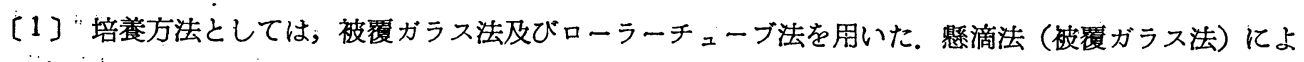

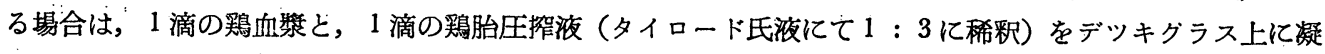
固せしめ, その上に組織細切片 $\left(0.5 \mathrm{~mm}^{2}\right)$ を移植し, ホールオヴシェクトにて被覆後, $37^{\circ} \mathrm{C} の$ 邲㽗器に静 睥し，原則として96封間培養を行つた。ローラチューブによる培養のためには，11 mm $\times 50 \mathrm{~mm}$ の短冊型， 溥貝の coverslip を予め調製し置き，ての上に被覆ガラス法と同様の手技で組織片を移植し，其の徐此答の

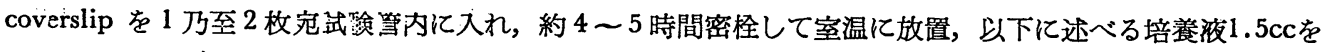

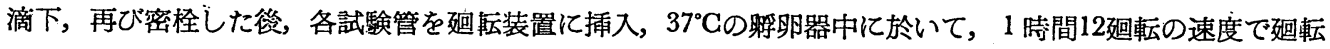
せしめた。乙の場合，培養液としては，鶏胎圧探液 $(1: 3) 0.3 \mathrm{cc}$, 癌性腹膜炎乃至肝硬変患者腹水 $0.3 \mathrm{cc}$, タイロード氏液 $0.9 \mathrm{cc} の$ 混合液を使用し，4 万至 5 日後交換した。

〔2〕組織片の採取：粰化後 7 日より17日に至る鷄胎膆組織を周い，別に，培養せざる膵組織について， 腺房及びラ氏島発生持期の概略を検索しつつ, 各跨期の膵組織につき, 体外培養を行つた. 極めて幼弱な膆 を摘法するためには，必要に応じて双眼ルーペを使用し，摘出の目的には，特に尖端の鋭い時計ピンャット

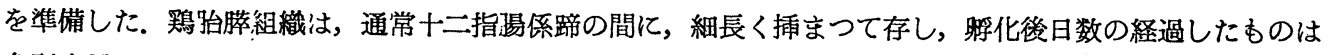
升別容易であるが，十二指昜䌽跻の未だ分化しない以前には，胃の尾側に存し，湿重量 $1 \mathrm{mg}$ に満たず, 組 織片 7〜8 ケを細切し得るに過ぎない.

〔3]組織学的乃至組織化学的考察の目的には，培養組織を一定時間，タイロード氏液に，coverslip と共 に入れ, $37^{\circ} \mathrm{C}$ の嘌卵器中に incubate し, 血墏膜の除去をはかつた後, Bouin 液にて短時間固定( 5 〜 10分),

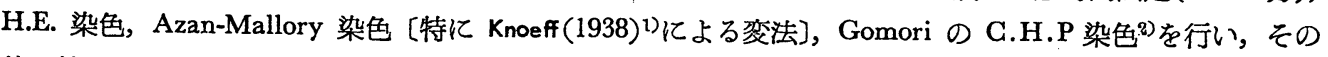
他，核酸染色として，メタノール固定後，Meygrunwald-Giemsa 染色3)，[Jacobson(1951)] を行い，細胸内 核酸分布の面から，培養細胞より島細胞を鑑別せんとした。培養せざる膵組織む Bouin 液に固定後，H.E. 染色, Gomori の C.H.P. 染色を行つた。

〔4]位相差顕微鏡的観察の目的には, 本学病理学教室 Ortholux [Leiz] 位相美湿徽鏡装置を用い, 必

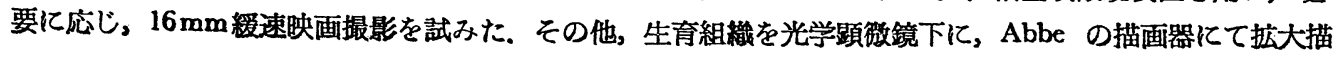


画し，Planimeter を用いて生育面積を計測，培養各日に於ける比翰成長価(R)を算出した．その算出要領は 下記の式に従 j。

$$
\mathbf{R}=\frac{\mathbf{B}-\mathbf{A}}{\mathbf{A}}
$$

$B:$ 生育面積 (発育帯十原面積)

A : 組織片原面積

$$
\text { III. 結果 }
$$

\section{〔1〕 発育模式及び生長度推移：}

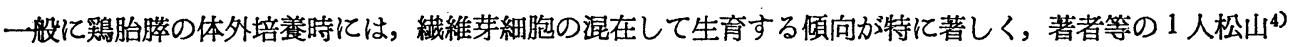

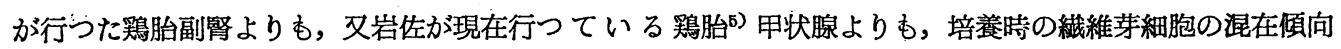
がつよい. 之は孵化後日数の経過した鵎胎膵組織培養時に著しく，放線状に発育した繊維芽細胞が旺盛な発

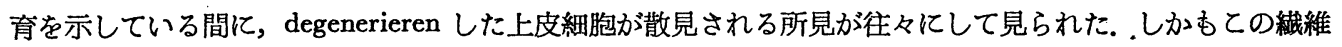
芽細胞白身す，同時に培養した鶏胎心組織の繊維芽細胞に比較すると可なり早期々り，原形質内に脂肪滴が

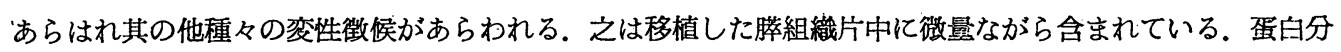
解醭素其の他の影響ではないかと推定される。殊にローラチューブ培養の場合，蛋白含量の多い癌性腹水を

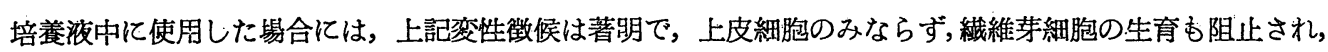
蛋白合量の少い肝硬変患者腹水を使用してはじめて，比較的長期間の培養に耐え，上皮細胞の再生す可能と

第 1 表 䳬胎膡培養 時の

Eplthelcer cell の生育状況

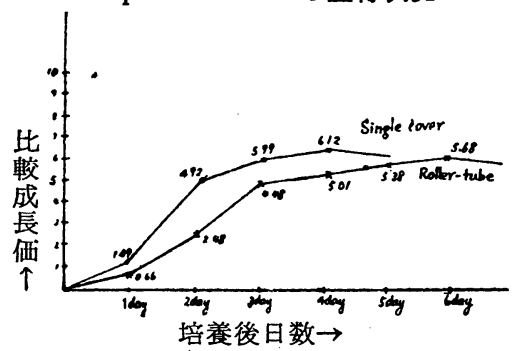

なつた，全般に上皮細胞の再生は全例中，約 35 万至 $40 \%$ 亿過 ぎなかつた. epitheliar sheeth を形成し，十分な発育をなし ていると認められた標本に就き，成長度を計測したが，その 培養直後より 24 時間毎に計測した比較成長価Rの推移仗第 1 表に示すでとくである.

即ち被覆硝子法の場合は，培養徐 1 乃至 3 日に急速な発育 を示し, 以後は培養細胞内に種々の退行幽变化を認め, 生長 あ緩徐乃至停止の傾向を示すに反し，ローラチ之ーブ法培養 時には，培養日数の絿過と共に，均一な坒育度を以て，徐々 に生育面積を増加し，培養惢 4 万至 5 日目に培養液を交換す るととにより，5 乃至 6 日間組織片を生存せしめるととを得

た. 染色䧣本により観察すると，ローラチューブによる培養些には，被覆硝子法培養時と比較して，発育し

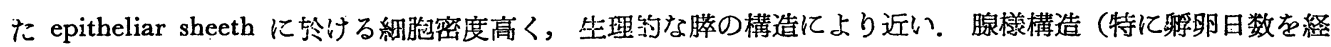
過したものに於いて）を示す傾向がつよい，0.5 mm² に細切した組織細切片を，更に鋭利なレザーにて細 挫引) (dissect) するときは，薄風の epitheliar sheeth (Fig.7, 9, 10) が得られるととが多いが，通常ローラ チューブ法培養特には， epitheliar sheeth は厚首で（Fig. 8，12）或る程度の立体的な構成を具えるてとが 譛められる，乙の樣な点から，ローラヂーブ法は被覆ガラス法よりも確かに優れた組織培養の方法である と云い得る。

次に瀻維芽細胞と epitheliar cell との鑑別の要点としては，前者は長軸に沿い放線状に発育する傾向があ

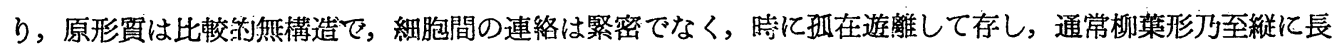
い紀鍾型を示し，不規則な形態をとるととが多い，之に反し柊者即ちepitheliar cell は紐胞間の連絡が緊密 であつて, 特異の細胞間突起を有するてとが多く, 通常集団を形成して存在する傾向あり，原形貝顆粒が豊 富である．乙の両著の鑑別は，位相差顕微镜下で極奶て適確に鑑別し得るが，染色漂本によつても，固定其 の他の操作間に細胞の変形を伴わない限り識別は不可能でない. 特に Jacobson 染色により, 䋖維芽細胞と 重なり合つて生育している epitheliar cell あ明確にとらえるてとが出来る. 即ち epitheliar cell は紼維芽

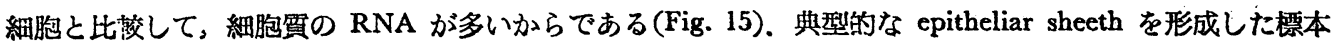


に就いては問題はなかつたが，菱型乃至紡䥀型を示す明らかに瀻維芽細胞と断定していい細胞が，Gomori の C.H.P 染色により焁青色に染宗り，原形䆩内に紫色の metachromasie を呈する顆粒を有する 所見が埘 に認められるととがあつた，細胸が培地中に孤在しているとと，又培地の近縁部の何処にむ epitheliar sheeth が認められないとと等より，此等の細胞は，やはり瀻維芽細胞と判定せざるを得なかつた。

〔2]位相差顕徽鏡所見 :

鶏胎膵培養時に再生する Epitheliar cell の微細構造を位相差顕微鏡により 観察すると，その形態上，大 略次の 3 つの型を観察，分類し得る．以下順を追つて之等を記載する.

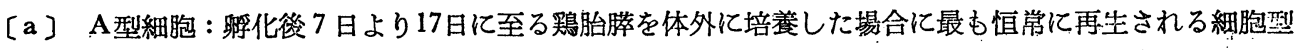
であつて, 多角形で通常典型的な epitheliar sheeth を形成し(Fig.1〜4), 大型の楕円形乃至円形の核と， 1 乃至 2 ケの核小体を認める，又核周辺微細な原形筫顆粒と，小型の桿棒状ミトコンドリアとが存する(Fig. 4) ミトコンドリアは織維芽細胞よりあ小型であつて Epitheliar cell の特性を具えている，てのA型細胞の

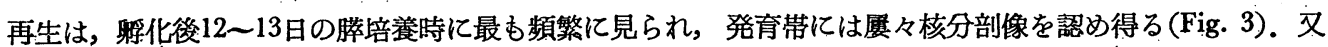
luxarious な epitheliar sheeth を形成するのは多くこの時期である（Fig. 1, 2 及び Fig. 11，12），射化後 7 日の奻弱な膵培養時にも同様のA型細胞の再生所見が見られるが，絨維芽細胞の混在して生育するてとも 間々あり，epitheliar sheethに 於ける核分剖数あ比較的少数である. 特にローラチューブ培養時に，epitheliar cell と瀻維芽細胞とが，一定の間隔を置いて互い違いに再生し，epitheliar sheeth が緎維芽細胞によつ て区切られたような観を示し，弱い腺様構造を示す所見が時折諗められる。

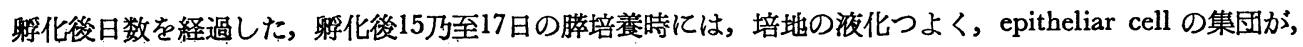
緎維芽細胞の下敷となつて再生する所見をみとめるてと多く(Fig. 15), 又 Fig. 8 のでとき厚層の epitheliar sheeth の再生像を琵めても，十分轼維芽細胞の混在が推定し得る.

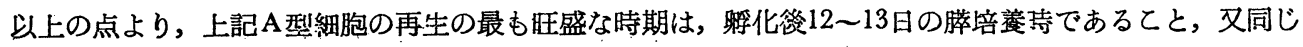

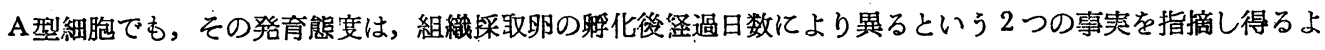
うに考える. 又A型細胞は組織棌取卵の粰化後経過日数により, 若干組織学的沂見をす異にする点があり, 之に就いては後に触れるととにする。

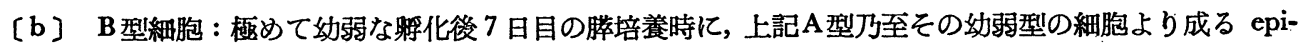
theliar sheeth の周辺部は，洔に厚層となり，細胞内原形質顆粒はその部に於いて特に豊富となり，その部 より 2，3 円形の epitheliar cell の遊離せんとする所見がみとめられる(Fig.6). 又 Fig.7 kは，同椂の細 胞が集団をなして索状に配列せんとする所見が認められる。乙の細胞は円形で，原形質顆粒を豊富に有し， 核は円形で 1 乃至 2 ケの核小体を有し，核は細胞体の 1 㑡に偏在するてとが多い。睬化後 9 日の膵咅養時に も，発育帯周辺部の薄層の epitheliar sheeth 中に同椂の円形の細胞の混在する所見をみとめた(Fig. 7 ). 乙 のB 型細胞は上記のでとく極めて奻弱な時期の膆培養侍に，すつとも屡々見られるようであるが，躬化後 15 日の膆培養侍に，僅少例ではあるが，同樣の細胞の発育帯周辺部に，或いは数個集合し，或いは培地に游出 している所見をみとめた． 細胞の両遠心端任 spindle like の突起を有する点で異つているが，集団を形成す る傾向があり, 又発育蒂の極く近縁に存し，原形賓頼粒が豊富である等の点から，緇維芽細胞と区別し得， 同様のB型細胞であると考えられる，しかし，紐胞はやや大型を示しているようであつた(Fig.9).

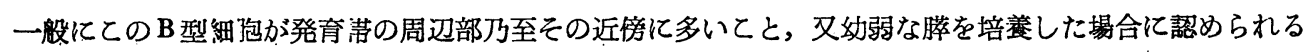
こと等は，或いはてのB 型细狍が $\mathrm{A}$ 紐胞の一つの変形に過ぎないという疑義を抱加しめないでもない. 即ち 幼弱なA 型細狍, 多角形の細狍が，培地の抵抗をうけて表面張力のために，単に円形に変形したあのに過ぎ ないのではないかという疑問である．細胞の形態のみによつてその帰属を判断するてとはての意味で尚危険 性が存するようである.

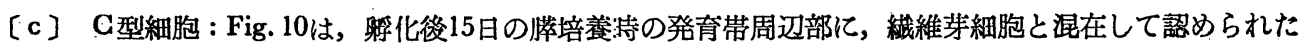
多角形の Epitheliar cell を示している，A型細胞よりも，原形幊顆粒が極わて 豊富である点に特異性があ り; B 型稩胞とす形熊上明らかに差異が存する. 


\section{[3] 粗的乃至粗浐化学的所見 :}

以上に於いて膵体外培養時に再生する Epitheliar cell について，位相差顕微鏡㓋察から推察される3 種の 練胞の形態的な特徵を記載したが，てれらの紐胞及びてれらの紐胞によつて構成される epitheliar sheeth が 如何なる組織学的乃至組織化学的特徴をむつかiてつて考察したので以下にその大要を述へる。.

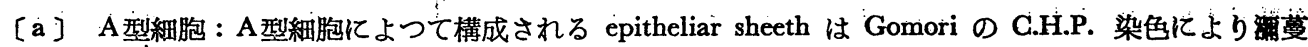
性に淡く青く染まるが，原形䆩内に gomoriphil の顆粒及び phloxin 好性の顆粒を証明し得ない (Fig.11,12). 躬化徐16日の膵培養時に再生したA 型紐胞の原形質内に，Azan-Mallory 染色により橙色に染まる顆粒をみ とめ, 又 Jaccbson 染色による RNA す，膵採取卵の躬化後経過日数と共认堌強する感があり，躬化後17日 膵培養時に再生した Epitheliar cell の内部に於いて，RNAが細胞の未端部に集積する所見が見られる(Fig. 17). 乙れらの所見はてのA 型紐胞が，膵外分泌の腺房細胞の系列に属する細胞であるという推定を成立さ

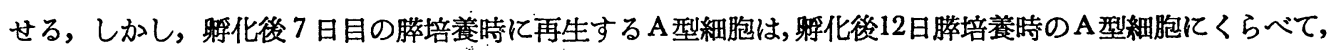
やや小型で，原形質も明調で，核の染色性乏しく，RNA む比較的少い(Fig. 13，14). 故にての時期の再生 $\mathrm{A}$ 型紐胞は腺房形成以前の未分化な細胞即ち膆始源細胞とであ名附けるべきであろうか。.

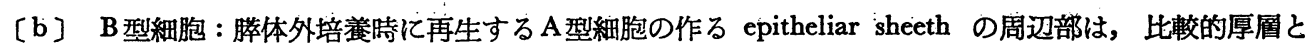
なり，ててに核分剖像も多いが，Gomori の C.H.P. 染色に対しても青色調が強い(Fig. 11，12)．奻弱な膡 を培養した場合，てとより 円形のB型細胞が遊離するととを 位相差像によつて 確認したが，ての細胞は Gomori の C.H.P. 染色に対し, 青染乃至灰青色に染まる原形質顆粒を有するてとが染色によつて判明した. 内分必腺を体外培養した場合，その発育帯周辺部は，一般に最も機能的に活性な部分であると推定される. 即ち著者らの 1 人松山4) は鷄胎副留培養㭙に，発育带周辺部に，皮質細胞の鋪石状発育をみとめており，又 岩佐 ${ }^{5}$ は甲状腺培養時に，該部の細胞に原形質顆粒が最も豊富で，しかもての顆粒は Azan Mallory 染色に より青文は赤く染色されると云い，又 Pomerat ${ }^{2}$ 門下の一人は，甲状腺培養時に，発育帯周辺部の細胞の原 形賀顆粒は I181 を提取するととを最近見出している，とすれば膵培養時の発育帯周辺部に Gomori 好性が 比較的つょく gomoriphil の原形質顆粒を有する小型の円形の細胞の游出像が見られてす，あながち首肯で きない專実ではないと思われる，乙れらの細胞は，上記染色所見から見て幼弱な $\beta$ 細胞の再生像であると推 定されるが，尚確言は差し控えたい。

[c] C 型細胞：ての細胞については，例数僅少で組織学的考察を行い得なかつた．B型紐胞よりも原形 實顆粒が denser である点から $\alpha$ 細胞でないかとも考えられるし，又多角形である点から A 型細胞の成熟型 であるかとあ考えられる， $\alpha$ 細胞については，粰化後16日の膵を培養した場合に再生したA型細胞の_sheeth 中に，Azan-Mallory 染色に対し，赤染する原形質顆粒を有する細胞が $2 ， 3$ 慧められた 1 例があつたてと を附記して置く.

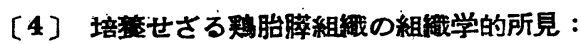

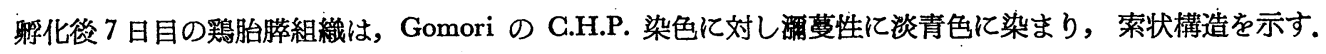
絧胞は一般に，培養再生細胞より小型で特に gomoriphil の顆粒，phloxin 好性の顆粒を証明せず，Azan 染 色に反応する顆粒を有しない，処々滴状に gomoriphil の場所があり，又phloxin 好性の部があるが紐胞構 造を有するか否加は明らかでない，垺化後8 日目より10〜11日にかけて腈を構成する細胞中に，'Azan-Mallory染色により orange 亿染まる顆粒を有するすのがあらわれ日数と共に漸次增加し，之は倠化隹14〜15 日には膆全野に明確にみとめられる。乙の少し以前躬化後12日～13日に於いて，膵は，はじめて明瞭な腚樣 構造を示し，射化後7日の膵とはかなりその構成が異つている.

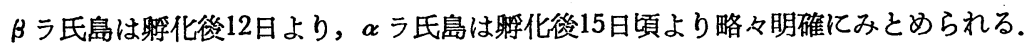

躬化後 7 日目の膵を構成する細胞と，睬化畧12日の膵を構成する細胞とを比較すると，前者に於いて，核 の染色性は劣り，核は一般に胞状であつてクロマチン少く，原形質む一般に明調であり，谽者に較へててら 幼弱と云う感がふかい。

組織培養に於いて，前記 $\mathrm{A}$ 型細胞が最も庄盛な発育を示す時期郎ち躬化後12〜13日に於いて膵の腺樣構造 
が略々完成し，その前後に於いて，体外培養に於いても，又組䋘学的考察に於いても，Azan Mallory 染色 による Zymogen granules の出現及び増加が見られるととは興味があり，之は前記A型紐胞が腚房細胞系 の細胞であるという著者等の推定に根拠を与える專実であるように思える. 又更に，躬化後 7 日目の膵培養 時に同様のA型細胞の幼弱型と考元る細胞の再生をみとめ, しかもその発育帯周辺部より, gomoriphil の原 形賈顆粒を有する細胞の再生像をみたてとは，鷄の胎生期膵に於いて，幼弱な腺房細胞と，幼弱な島細胞之 が，始源細胞 (cellulae pancreaticus primitiva) と屯いうべき同一未分化細胞より発生しはじめるのでない かという推定を成立せしめる：最近戸刚8）す，膵島紐胞の発生について，下垂体前葉紐胞の色素嗜好性細胞 と同一経過をとるといい， $\alpha, \beta$ 両細胞 (及び腺房細胞) は，同じ萃未分化細胞上り発生するとし， 互に異つ た方向に分化発展して, 各々の相互移行は誌められないと述べており，氏の論は主として哺乳動物に就いて であるが，鶏に於いでま之は罗当するのではなかろうか.

\section{IV. 考察}

膵藏の体外培養に関する報告は，外国では既に Pinkus H.9)(1929)によつて行われ，腺及び排泄管及び時折 ランゲルハンス氏島紐胞を再生し得，核分剖像，分议顆粒を認め得たと記載されている．其の他 Fischer 1.10)（1937）の報告，我が国ではただ 1 人鈴木 ${ }^{11)}(1928)$ の報告があるが，何れも Gomori の C.H.P. 染色， Azan-Mallory 染色の記載以前の報告である点，それらの記述を全面的に受け容れるととは出来ない．

鶏胎膵の組織発生について，現在に於いてもその用いた染色法の点で，最も信頼度の高い報告はVillamil M.F. (1942)によるものであるが, Villamil は，睬化後 8 日目に於いて，膵末分化細胞より腺房紐胞が発生 するととを, Ażan 染色によつて浔め, 同じ時期に, 同一脪未分化紐胞より, Azan 染色により，明暗 2 種 に区別し得る幼弱な島細胞が分化すると述へ，明調細胞は，躬化徐12日頃その一部は変性し，残部は $\beta$ 顆粒

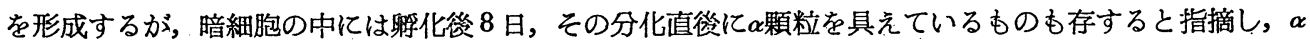
細胞は一般に媵の distal end そ局在し， $\beta$ 紐胞は勝全野にわたつて散在すると述べている.

吾々の成績む，腺房形成時期の点では，上記結果と一致するが，幼弱な島紐胞の発生起始時期については 必ずしも一致しない，吾々の成䋶では $\beta$ ラ氏島と略々明確に断定し得る所見は㑗化後12日に認められ，其の 以前には，滴状 gomori 陽性の部分乃至 $2 ， 3$ の微小な gomori 陽性細胞の集団と認められる所見を認めた に過ざず， $\alpha$ 細胞についてむ， $\beta$ 紏胞と略々同㥞の所見は認められたが，明確な $\alpha$ ラ氏島は捊化後 14 万至15 日に於いて認められた，島紏胞と推定される紐胞は，幼弱期に向うに従つて極めて微小であつて，その細胞 構造を明確に認め得ないてとが多く，確言を差し控えたのである. 何れにしても，吾々の成績に於いても， 睬化後 ? 乃至 8 日目より，滴状に gomori 乃至 phloxin 好性の部分が存するてとは專䒠であり，腺房分化以

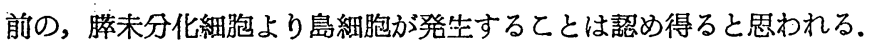

Hard，W.L. ${ }^{13)}$ (1944)，Bencosme S.A.14) (1955) 等は，哺乳類に就いて実験し，膵初期排泄管上皮より，embryonic islet が発生するてとを認めており，吾が园の戸㺫も前述のでとく，之を主張しているので，鶂て於 いても膵未分化細胞より直接幼搦な島細胞が発生するてとを認めてもよいと思われ，吾々の上記成績及び Villamil の实駼加ら之は主張し得る.

尚吾々の培養実験に於いて，幼弱な $\beta$ 細胞の再生が認められたに拘らず，幼弱な $\alpha$ 細胞の再生像に接し得 なかつたととは，Villamil の主張するでとく $\alpha$ 細胞か膵の distal end に局在する故かす知れない. 膵の distal end を分離して培養すれば $\alpha$ 細胞の再生す得られるかとも思われる：何れにしてあ，脇体外培養時に 再生する細胞は, 腺房細胞系の細胞が多数を占め, ラ氏島細胞の再生を恒常に得るととは, やはり困難であ ると云う結論に到達せざるを得ないようである。

\section{V. 結}

論

1）鴊胎膵体外培養時に再生する epitheliar cell は大部分膆未分化紏胞乃至之から発展したと考えられる腺 房細胞であつて，ラ氏島細胞の再生は少くとも恒常には起りがたい． 
松山, 岩佐, 天田論文附図 (其の一)

培養鷄胎脺組織の位相差顕微鏡所見

Fig. 1

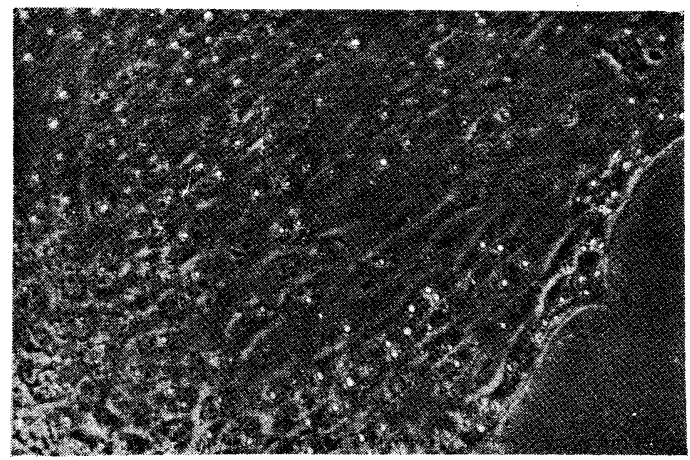

Fig. 3

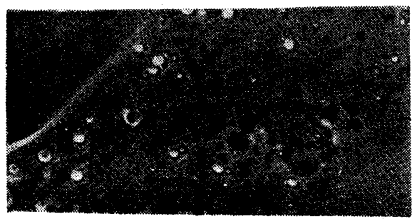

Fig. 4

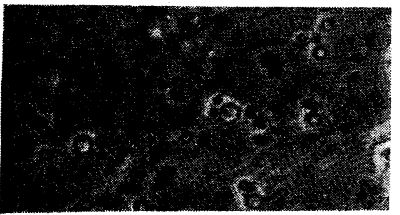

Fig. 5

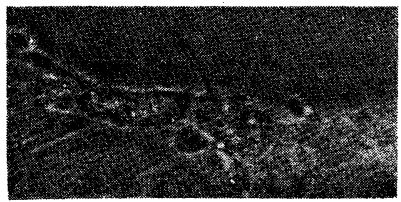

Fig. 9

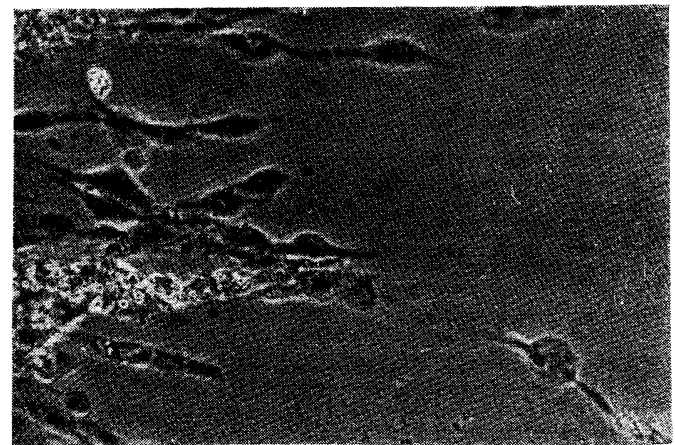

Fig. 2

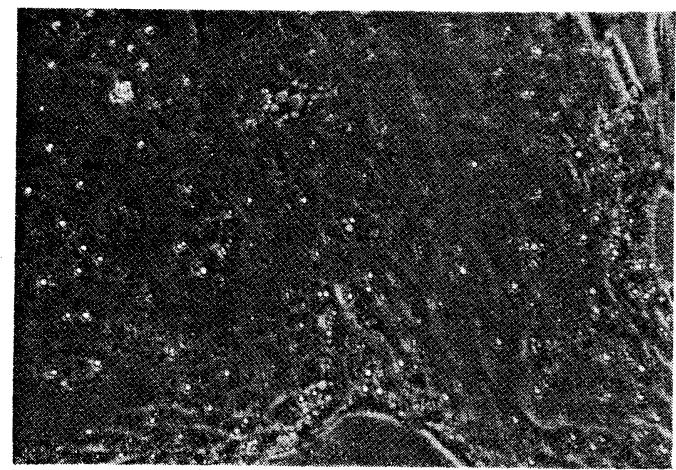

Fig. 6

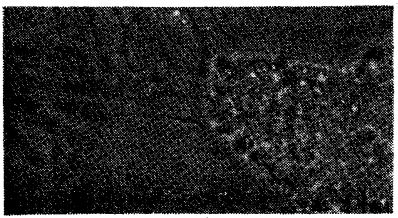

Fig. 7

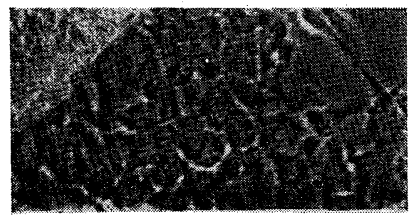

Fig. 8

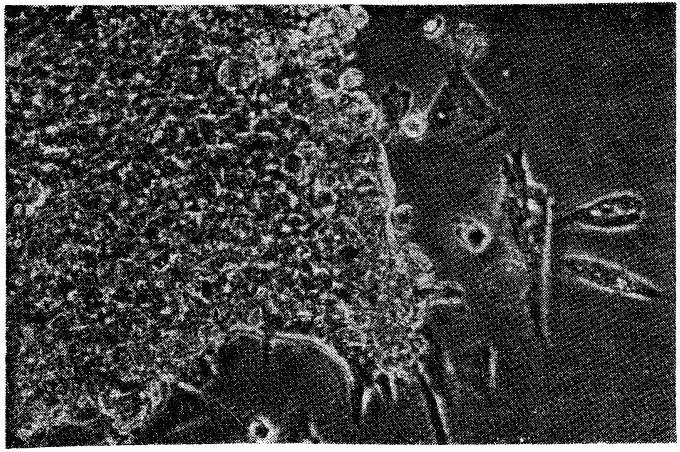

Fig. 10

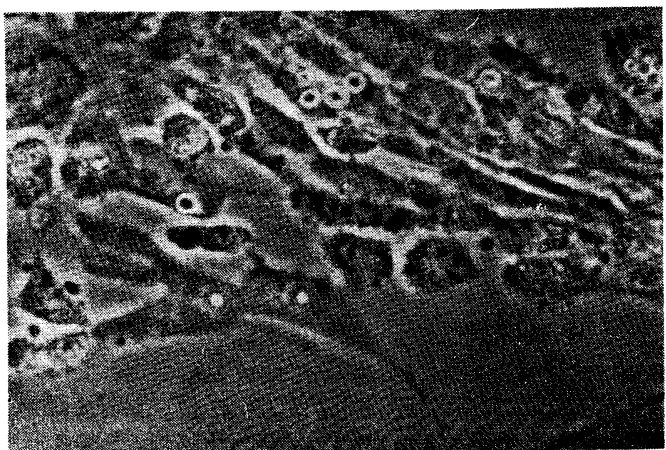


松山, 岩佐, 天田論文附図 (其の二)

培盖した鷄胎脺組織の組織学的乃至組織化学的所見

Fig. 11

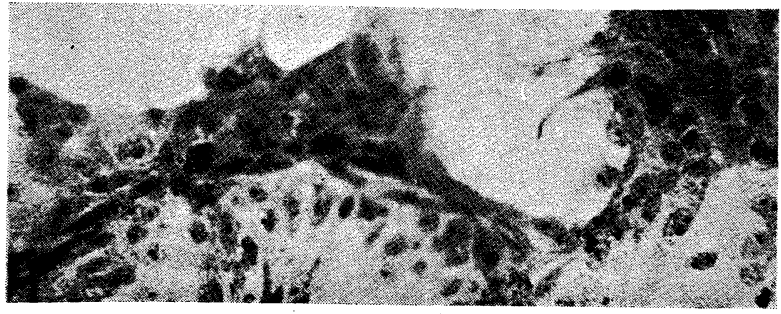

Fig. 12

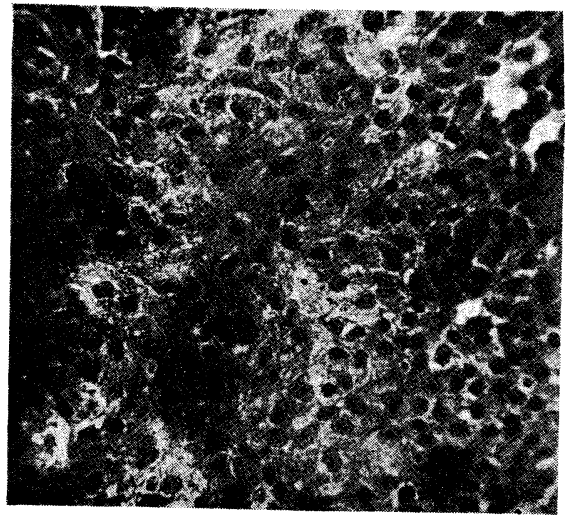

Fig. 15

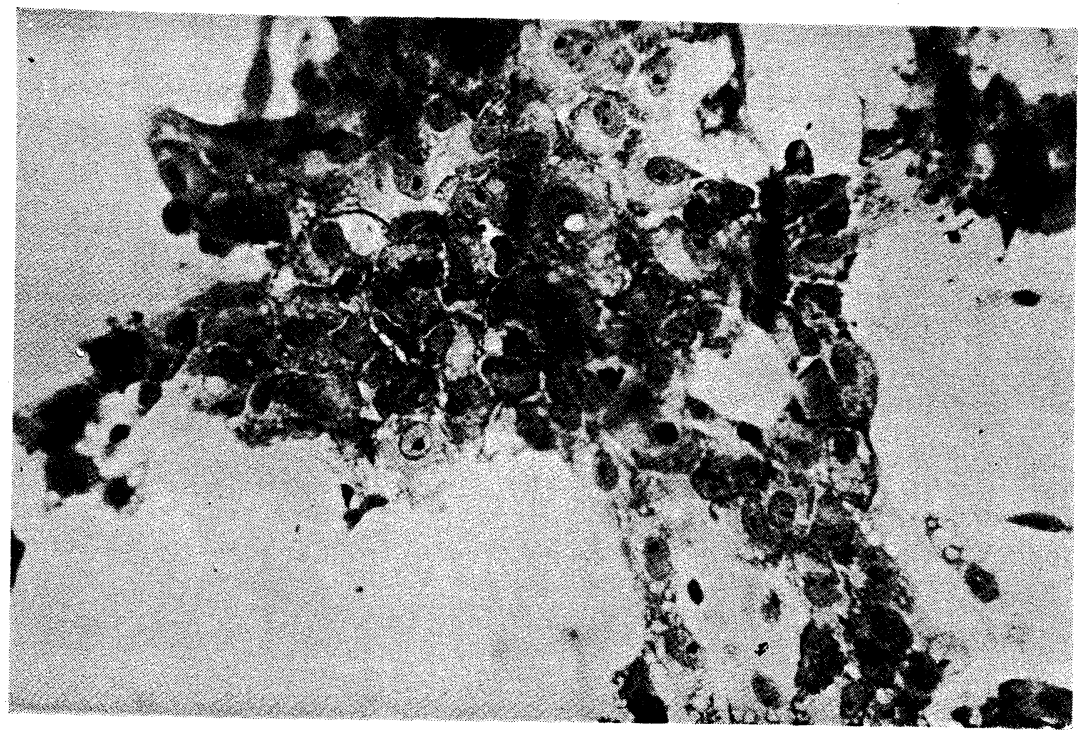


2）培養した膵の発育帯周辺部に Gomori 好性が比較的強く，機能的にての部は注目してよい。

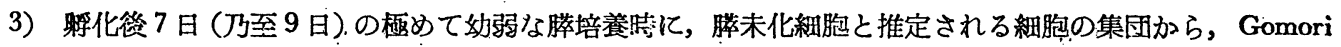

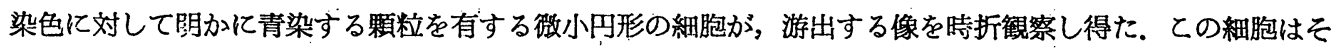
の染色所見汃ら奻弱な $\beta$ 細胞であると略々断定し得る。

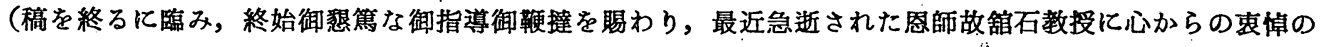
念を捧げると共に, 御校閲を睗わつた吉田秀雄助教授, 位相差顕微鏡につき種々御指導を睗わつた本学病理 学教室荒木正哉教授，三宅清雄講師に厚く感謝いたします.)

尚本研究はワックスマン財団助成金に負う所大であり，記して謝意を表します。

\section{引用文献}

1) Knoeff A.A. : Stạin Technology 13, 49 (1938).

2) Gomori G, : Am. J. Path. 17, 395 (1941).

3) Jacobson W. and Wẹbb W. : Exper. Gell. Res. 3, 163 (1951).

4）松山惧一：日本内分缶学会

誌, 33, 580 (1957).

5) 岩佐五肉 : 日本内分必学会誌, 34, 202 (1958).

6) Guillemin R.

and B Rosenberg : Endocrinology 57, 599 (1955).

7) Pomerat C.M. : 未発表.

8) 戸刈近太郎 :

内分泌のつどい(第 8 集), 28, 協同医書出版社 (1956).

9) Pinkus H. : Arch. Exp. Zellforsch. 8, 130 (1929). 10) Fischer I. : Z. Zellfors. 27, 640 (1937).

11）鈴木清：臨林病理 学血液学雄誌,

3, 122 (1934).

12) Villamil M.F. : Rev. Soc. arg. de biol., 18, 416 (1942).

13) Hard. W.L. :

Am. J. Anat., 75, 369 (1944).

14) Bencosme S.A. : Am. J. Anat., 96, 103 (1955).

\section{附 図 説 明}

\section{〔 I 〕 位相差顕微鏡所見}

Fig.1。睬化後12日腾 3 日培養後再生した luxarious epitheliar sheeth（被覆ガラス法）[×150]

Fig.2. 同上. 他の例を示す. $[\times 150]$

Fig.3. 同上. 核分剖像（終期）を示す. [x450]

Fig.4. 同上. epitheliar sheeth を構成する細胞の微細構造を示す。 $[\times 750]$

Fig.5. 㽟化後 7 日膵 3 日培養後再生した上皮紐胞索。内形紐胞の游出所見をみとめる。（ローラチ ユーブ法) [×150]

Fig.6. 㽟化後 7 日滕 3 日培養後, 再生した epitheliar sheeth の周辺部。同上円形緗胞に注意（口 ーラチューブ法) [×150]

Fig.7. 睬化後 9 日膵 5 日培養後再生した fine epitheliar sheeth. (ローラチユーブ法) [×150]

Fig.8. 粰化後15日滕 5 日培養後再生した厚首の epitheliar sheeth（ローラチユーブ法）〔×150]

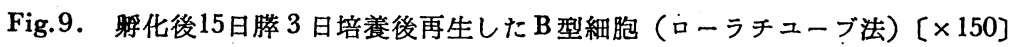

Fig.10粰化後15日膵 5 日培養後再生した $\mathrm{C}$ 型細胞（ローラチユーブ法）[×150]

[I]咅養組瀻の組織学的所見

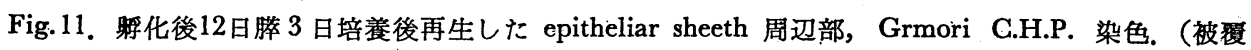
ガラス法） [×350]

Fig.12. 埒化後12日滕 3 日培養後再生した epitheliar sheeth. 左が発育帯周辺部，Gomori C.H.P. 染 色（ローラチユーブ法） [×350]

Fig.13. 將化後 7 日膵 3 日培美後再生した epitheliar sheeth 周辺部, 微小な円形細胞の游出鮘 Gomori G.H.P. 染色（被覆ガラス法）[×350]

Fig. 14. 同上. 他の培養標本

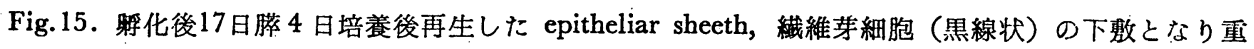
なり合つて再生. Jacobson 染色（ローラチューブ法）[×350, 引伸 $]$ 